\title{
Тувинская Народная Республика накануне вхождения в состав СССР глазами советского дипломата
}

\author{
Иванна В. Отрощенко \\ Институт востоковедения им. А. Е. Крымского Национальной академии наук Украины, \\ Украина
}

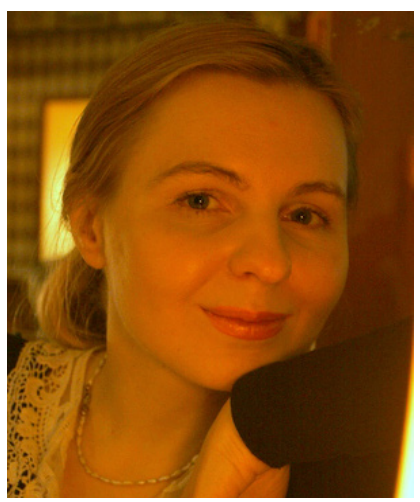

В статье исследуется ряд резонансных аспектов политической истории Тувинской Народной Республики накануне ее присоединения к Советскому Союзу. Дневниковые записи поверенного в делах СССР в ТНР М. Г. Сущевского (1942-1943) позволяют, в частности, проанализировать ранний, подготовительный этап этого процесса и локализировать хронологическую дату, с которой советское руководство начало прорабатывать этот вопрос, - 18 марта 1943 г. Уделяется внимание и другим явлениям общественнополитической жизни ТНР, связанным с принятием тувинской элитой решения о присоединении к СССР, таким как деятельность государственных органов (Малого хурала), политические репрессии, которые продолжались в республике и в 1940-е г2.

Освещаются вопросы эмиграции тувинских аратов в МНР и принудительное переселение этнических тувинцев из Монголии в Туву 1930-1940-х г2. Рассматривается вопрос о границе, который с начала 1930-х г2. стал ключевым в отношениях между МНР и ТНР и оставался таким до вхождения Тувы в состав СССР в октябре 1944 года.

Исследование опирается в том числе на неопубликованные «Дневники поверенного в Делах СССР в ТНР т.т. Сущевского и Бударина». 10.12.1942-30.11.1943», которые хранятся в Архиве внешней политики Российской Федерации, в фонде 06 «Секретариат В. М. Молотова».

Ключевые слова: Тувинская Народная Республика; СССР; Малый хурал; международные отношения; Монгольская Народная Республика; Салчак Калбакхорекович Тока; Александр Мангеевич Чимба; Михаил Григорьевич Сущевский; тувинцы; монголы; староверы Тувы; история Тувы; политические репрессии

\section{Для цитирования:}

Отрощенко И. В. Тувинская Народная Республика накануне вхождения в состав СССР глазами советского дипломата [Электронный ресурс] // Новые исследования Тувы. 2019, № 4. URL: https://nit.tuva.asia/nit/article/view/895 (дата обращения: дд.мм.гг.). DOI: 10.25178/nit.2019.4.17

Отрощенко Иванна Витальевна - доктор исторических наук, ведущий научный сотрудник отдела современного Востока Института востоковедения им. А. Е. Крымского Национальной академии наук Украины; главный редактор журнала «Східний світ» («Мир Востока»). Адрес: 01001, Украина, г. Киев, ул. Грушевского, д. 4, к. 226. Эл. адрес: shidnyj.svit@gmail.com

Otroshchenko Ivanna Vitalievna, Doctor of History, Leading Research Fellow, Department of the Modern East, A. Yu. Krymskyi Institute of Oriental Studies, NAS of Ukraine; Editor-in-Chief, Shìdnij svit (Mir Vostoka). Postal address: Apt. 226, 4 Hrushevskyi St., 01001 Kyiv, Ukraine. Email: shidnyj.svit@gmail.com 


\title{
Tuvan People's Republic on the eve of accession to the USSR through the eyes of a Soviet diplomat
}

\author{
Ivanna V. Otroshchenko \\ A. Yu. Krymskyi Institute of Oriental Studies, NAS of Ukraine, Ukraine
}

The article examines a number of key aspects in the political history of Tuvan People's Republic shortly before it became part of the USSR. The entries in the diary of the charge d'affaires of the USSR in the Tuvan People's Republic, M. G. Sushchevsky (1942-1943) help us focus, in particular, on the early preparatory stage of this process and pinpoint the date when the Soviet leaders started to consider the issue quite seriously - March 18, 1943. Attention is also paid to other developments in the social and political life of the People's Republic of Tuva which had some bearing in the process of taking the decision to join the USSR. Among them are the government institutions and their work (e.g. the Little Khural) and the political purges which continued into the 1940s.

Some light is shed on the emigration of Tuvan arats to Mongolia and the forced resettlement of ethnic Tuvans from Mongolia to Tuva in the 1930s and 1940s. Special treatment is given to the issue of the border which since the early 1930s had become dominant in the Tuvan-Mongolian relations and remained so until the accession of Tuva into the USSR in October 1944.

For its sources, the study, inter alia, relies in the unpublished "Diaries of the charge d'affaires of the USSR in the Tuvan People's Republic c [omrades] Sushchevsky and Budarin", preserved at the Archives of the Foreign Policy of the Russian Federation (f. 06 “V.M. Molotov's Secretariat”).

Keywords: Tuvan People's Republic; USSR; Little Khural; international relations; Mongol People's Republic; Salchak Kalbakkhorekovich Toka; Aleksandr Mangeevich Chimba; Mikhail Grigor'evich Suhschevsky; Tuvans; Mongols; Old Believers in Tuva; history of Tuva; political repressions

Otroshchenko I. V. Tuvan People's Republic on the eve of accession to the USSR through the eyes of a Soviet diplomat. The New Research of Tuva. 2019, № 4. URL: https://nit.tuva.asia/nit/article/view/895 (access date ...). DOI: 10.25178/ nit.2019.4.17

\section{Введение}

Одним из многочисленных неопубликованных источников по истории Тувы середины XX века являются «Дневники поверенного в Делах СССР в ТНР ${ }^{1}$ т.т. Сущевского и Бударина». 10.12.1942-30.11.1943». Дело с таким названием хранится в Архиве внешней политики Российской Федерации, в фонде 06 «Секретариат В. М. Молотова» (Архив внешней политики Российской Федерации - далее АВП РФ. Ф. 06, оп. 5, п. 31, д. 363) 2 . Сухие и лаконичные записи, сделанные незадолго до вхождения Тувы в состав Советского Союза, содержат немало полезной информации, позволяющей реконструировать разные стороны жизни тувинского общества. Большая часть из этих записей принадлежит поверенному в делах СССР в ТНР Михаилу Григорьевичу Сущевскому (1942-1943).

Особый интерес представляет информация, так или иначе связанная с обстоятельствами резонансного объединения, продолжающая оставаться затребованной, как в научном, так и в общественном дискурсе. Немаловажными и интересными являются и сведения, касающиеся С. К. Токи, неоднозначного исторического деятеля, сыгравшего огромную роль в судьбе Тувинской Народной Республики. Насколько можно судить, вокруг его фигуры и политической деятельности в самой Туве не утихают дискуссии (см.: Салчак Тока, 2015: 6-14), и голос беспристрастных документов в такой ситуации не перестает быть актуальным.

${ }^{1}$ ТНР - Тувинская Народная Республика (1921-1944 гг.).

${ }^{2}$ Ознакомиться с этим делом (как и рядом других дел, касающихся истории ТНР и советско-тувинских контактов периода Второй мировой войны), стало возможным благодаря масштабному проекту: СССР и союзники. Документы Архива МИД России о внешней политике и дипломатии ведущих держав антигитлеровской коалиции. URL: http://agk.mid.ru/ (дата обращения: 25.03.2019). 
Целью данной статьи является исследование разных сторон общественно-политической жизни ТНР накануне ее присоединения к Советскому Союзу и раннего, подготовительного этапа этого процесса, связанные с ним обстоятельства и нюансы, которые ранее не попадали в поле зрения исследователей. Предметом анализа являются и советско-тувинские отношения в этот период, которые развивались уже под влиянием негласных «объединительных» тенденций. Это позволит автору глубже раскрыть хронологию и внутренние механизмы резонансной, но, на самом деле, малоизвестной и заидеологизированной страницы тувинской истории.

\section{Политическая ситуация в Тувинской Народной Республике накануне вхождения в состав СССР}

Поверенный в делах СССР в ТНР М. Г. Сущевский к исполнению своих обязанностей на тувинской земле приступил 10 декабря 1942 г. Пробыл он на этой должности до начала ноября 1943 г. Период этот был очень насыщенный и интересный с точки зрения укрепляющихся тенденций в советском и тувинском руководстве относительно присоединения ТНР к СССР.

Из обращения 26 июня 1944 г. ЦК ТНРП и правительства ТНР в ЦК ВКП(б) на имя наркома иностранных дел В. М. Молотовым и секретаря ЦК ВКП(б) Г. Маленкова нам известно, что: «Еще в 1941 г. Политбюро ЦК ТНРП официальным письмом возбудило ходатайство о принятии ТНР в состав Советского Союза. В 1943 г. эта просьба в беседе с Вами, товарищ Молотов, возобновлялась. Но вопрос этот по обстоятельствам внешнеполитического характера был отложен...» (цит. по: Харунова, 2011: 52). В марте 1943 г., во время своего посещения Москвы, пылкий сторонник объединения, генсек ТНРП С. Тока был на приеме у Молотова. Известно, в частности, что их беседа состоялась 18 марта 1943 г., и она не записывалась (АВП РФ. Ф. 06, оп. 5, п. 3, д. 30, л. 106). Но из записей М. Сущевского мы узнаем, о чем там могла идти речь. Вернувшись в Туву, 7 апреля на заседании Политбюро ЦК ТНРП С. Тока рассказал, что «на приеме Делегации т. Молотовым В. М.» среди прочего поднимался и вопрос «об условиях присоединения ТНР к СССР» (АВП РФ. Ф. 06, оп. 5, п. 31, д. 363, л. 17).

Подтверждением подобных размышлений советской стороны в этот период может служить «Справка о Тувинской Народной Республике», составленная по материалам 3-го Дальневосточного отдела НКИД и датированная 11 апреля 1943 г. (АВП РФ. Ф. 06, оп. 5, п. 31, д. 364, лл. 7-27). В «Справке» содержалась краткая информация об истории и народном хозяйство ТНР, заключительными шли сведения о тувинских кадрах, где акцентировалось на лояльности тувинской политической элиты и руководства, которое «горячо предано СССР и твердо проводит курс на тесное сближение с нашей социалистической родиной» (АВП РФ. Ф. 06, оп. 5, п. 31, д. 364, лл. 26). Например, про Александра Мангеевича Чимбу, председателя Совета министров ТНР, писали, в частности, следующее: «Вполне советский человек, безусловно поддерживает Тока в проведении политики сближения ТНР с СССР вплоть до присоединения, весьма дружелюбно относится к сов. гражданам» (АВП РФ. Ф. 06, оп. 5, п. 31, д. 364, л. 27; подчеркнуто карандашом в документе. - И. О.).

В своих записях М. Сущевский также отмечает, что 24 мая «беседовал с Чимба по поводу решения ЦК ВКП(б) от 5/IV 1943 года. Решение получено в Кызыле 22 мая 1943 года» (АВП РФ. Ф. 06, оп. 5, п. 31, д. 363, л. 24). Возможно, это решение касалось именно перспективы присоединения Тувы к СССР и содержало потенциальное согласие советской стороны. Косвенным подтверждением таких намерений может служить более позднее решение Политбюро ЦК ТНРП от 25 августа 1943 г., о котором также сообщает М. Сущевский, - в Кызыле и во всех хошунных центрах организовать занятия по изучению русского языка тувинскими служащими и тувинского языка советскими гражданами - служащими учреждений (2 раза в неделю в течение одного года) (АВП РФ. Ф. 06, оп. 5, п. 31, д. 363, л. 49). Тогда было решено также организовать обучение тувинскому языку школьников русских школ.

В свете таких тенденций интересен факт полемики между советскими дипломатами и тувинскими политиками о форме и знаках отличия в тувинской армии. 19 января 1943 г. в беседе с В. Г. Деканозовым ${ }^{1}$ тувинский премьер А. Чимба заявил, что, в связи с введением новой формы и знаков отличия в Красной армии, правительство ТНР намерено ввести новую форму и у своих военных. А. Чимба просил согласия на это советского правительства, утверждая, что форма Красной армии имеется в $\mathrm{HPA}^{2}$ со времен ее

${ }^{1}$ В. Г. Деканозов - заместитель наркома иностранных дел СССР (1939-1947). В его ведении были Иран, Турция, Афганистан, Монголия, Китай, Синьцзян и, похоже, Тува.

${ }^{2} \mathrm{HPA}$ - Народно-революционная армия (1934-1944). 
организации, к этому уже привыкло население и введения другой формы не поймут (АВП РФ. Ф. 06, оп. 5, п. 31, д. 363, л. 4). Во время пребывания в Москве А. Чимба, а затем С. Тока ставили этот вопрос перед В. М. Молотовым, который посоветовал иметь собственную форму и знаки отличия для НРА, отличные от формы Красной армии.

25 мая 1943 г. Сущевский беседовал с Токой по этому же вопросу: «Несмотря на указания, которые давались в момент пребывания его в Москве и указания, полученные на днях советником НРА т. Смахтиным, Тока дал указания заказать в Советском Союзе знаки отличия, которые приняты в Красной Армии» (АВП РФ. Ф. 06, оп. 5, п. 31, д. 363, л. 24). Например, на пуговицах высшего командного состава НРА был изображен герб Советского Союза, а не ТНР. Сущевский просил Току учесть «указание НКИД» про необходимость, поскольку Тува является самостоятельным, суверенным государством, разработать для НРА собственную форму и знаки отличия и заказать их в СССР (АВП РФ. Ф. 06, оп. 5, п. 31, д. 363, л. 24). Но тувинское руководство стояло на своем. 2 июля 1943 г. в беседе с В. Г. Деканозовым 2-й секретарь ЦК ТНРП Базыр-Сат снова просил разрешения ввести в армии ТНР форму и знаки отличия Красной армии и даже заказать в Госзнаке аналогичные советским значки физкультурников (АВП РФ. Ф. 06, оп. 5, п. 4, д. 40, л. 49). Инициатива тувинской стороны так и не нашла поддержки в Москве, и вскоре М. Сущевский рассказывает о заседании Политбюро ТНРП 21 июля, где, в частности, обсуждалось утверждение формы пагонов и знаков отличия для бойцов и командиров тувинской армии: «после отказа Советского Правительства от присвоения формы Красной Армии, разработана собственная, отличная от Красной Армии форма пагонов и знаков отличия для НРА» (АВП РФ. Ф. 06, оп. 5, п. 31, д. 363, л. 39).

Высшим органом государственной власти ТНР являлся Великий хурал - парламент, ответственный за установление основных принципов внешней и внутренней политики (по ст. 16 Конституции ТНР 1941 г.). Исполнительная власть в Туве принадлежала правительству, избранному Малым хуралом, и президиуму последнего. Некоторые исследователи отмечают, что в 1930-е гг. Великий хурал в ТНР постепенно терял свое значение, все реже проходили очередные собрания, после 1930 г. он работал в 1935, 1938 и 1941 гг. (Ондар, 2016: 161). При этом одновременно возрастало значение Малого хурала и его президиума. С конца 1930-х гг. все решения ЦК ТНРП стали утверждаться только президиумом Малого хурала, в состав которого входили от 5 до 7 человек (там же), по Конституции 1941 г. количество увеличивалось до 9 человек. Показательно, что декларация «О вхождении ТНР в состав СССР» была принята Малым, а не Великим Хуралом. Поэтому характер и особенности его деятельности в этот исторический период представляют особый интерес для исследователей.

Как Малый Хурал иногда принимал «нужные» решения, можно проиллюстрировать следующим ярким примером. 1 мая 1943 г. М. Г. Сущевский в своем дневнике писал следующее: «Опубликовано постановление Малого Хурала ТНР о присвоении Генеральному секретарю ЦК ТНРП т. Тока звания генерал-лейтенанта. Это постановление для многих явилось совершенной неожиданностью, так как Президиум Малого Хурала не собирался, а председателем Малого Хурала является Анчима, жена т. Тока. По существу т. Тока получил воинское звание лишь путем “согласования” с секретарями ЦК (Базырсат, Талганчик и др.), которые никогда в таких случаях не станут возражать» (АВП РФ. Ф. 06, оп. 5, п. 31, д. 363, л. 21). Заканчивая эту историю, Сущевский добавлял: «Советник ЦК ТНРП т. Калиничев с ведома которого проведено это решение, не счел нужным посоветоваться ни со мной, ни с Жуковым» (АВП РФ. Ф. 06, оп. 5, п. 31, д. 363, л. 21).

Выписки из дневника М. Сущевского позволяют коснуться еще одной проблемы, - политических репрессий в тувинском обществе. Информация об этих трагических событиях 1920-1950-х гг. в научной литературе довольно лаконична и, как правило, ограничивается сведениями о наиболее резонансных процессах, касающихся политической элиты республики (1932 и 1938) ${ }^{1}$. Если в 1930-е гг. работники советского полпредства во главе с полпредом И. Т. Мулюкиным принимали непосредственное участие в выявлении и устранении «врагов народа» в тувинском обществе путем искусственной фабрикации дел (Моллеров, 2005: 202), то в 1940-е гг. ситуация несколько изменилась. Такой вывод можно сделать, исходя из следующих записей М. Сущевского. 29 января 1943 г., пообщавшись с членами тувинского правительства, он узнал, что арестован ряд членов правительства: председатель ЦК Профсоюза Ш. Лопсан-Самбуу (Лувсан-Самбуу) и бывший министр земледелия Т. Сюрюн, подозреваемые в соучастии в контрреволюционном заговоре против правительства ТНР. «Среди русских работников

${ }^{1}$ Приятным и содержательным новшеством стала кандидатская диссертация О. Ю. Иргита: «Политические репрессии в Тувинской Народной Республике в 1921-1944 гг.» (Иргит, 2019). 
арестованных нет», - отмечал Сущевский (АВП РФ. Ф. 06, оп. 5, п. 31, д. 363, л. 11). В дальнейшем о результатах следствия по делу Ш. Лопсана-Самбу и Т. Сюрюна он пытался узнать у А. Чимбы, который обещал дать выписку из показаний обвиняемых.

Позднее советский дипломат побеседовал на эту тему с инструктором МВД ТНР М. М. Рапопортом. Так, 15 марта 1943 г. у них состоялся разговор о необходимости ставить в известность миссию об аресте советских граждан и политических делах, фигурантами которых являются тувинские граждане. М. Сущевский, в частности, просил ознакомить его с делом Ш. Лопсана-Самбу и Т. Сюрюна ${ }^{1}$. М. Рапопорт отказался это сделать, ссылаясь на то, что у него есть прямые указания НКВД никого, в т. ч. и посланника, с материалами МВД не знакомить и что в санкциях на арест советских граждан, проживающих в Туве, он не нуждается (АВП РФ. Ф. 06, оп. 5, п. 31, д. 363, л. 11). 8 июня 1943 г., когда поступили сведения об арестах МВД ТНР 4-х советских граждан, Сущевский снова поинтересовался у Рапопорта, почему об арестах советских граждан и, в частности, членов партии не извещают советскую миссию. М. Рапопорт ответил: «Мы согласовали аресты с Тока. У меня имеются прямые указания НКВД на этот счет» (АВП РФ. Ф. 06, оп. 5, п. 31, д. 363, л. 30). М. Сущевский заключил, что, видимо т. Рапопорт никаких новых указаний по этому вопросу из Москвы не получал. Советский дипломат констатировал, что в ТНР широко практикуется, как лучшая мера пресечения, арест обвиняемых.

20 июля 1943 г. в Кызыле были получены поздравительные телеграммы заместителя Председателя Совета Народных Комиссаров Л. П. Берии, наркома государственной безопасности СССР В. Н. Меркулова, начальника 1-го Управления НКВД СССР П. М. Фитина, А. И. Лангфанга ${ }^{2}$ на имя С. К. Токи, министра МВД ТНР Н. Ч. Товарищтая по поводу 18-летия МВД и награждения Токи, Товарищтая, заместителей министра МВД ТНР С. Парчына и М. Артаса почетными значками НКВД СССР: «Награждение значками НКВД СССР работников МВД ТНР вызвало большую радость и удовлетворение в Правительственных кругах», - отметил М. Сущевский (АВП РФ. Ф. 06, оп. 5, п. 31, д. 363, л. 39).

\section{Тувинско-монгольские контакты}

Вопрос о границе с начала 1930-х гг. стал ключевым в отношениях между МНР и ТНР и оставался таким до вхождения Тувы в состав СССР в октябре 1944 г. Линия государственной границы между двумя республиками была определена, при содействии советской дипломатии, Соглашением 1932 г., однако не была демаркирована. Монгольская сторона неоднократно поднимала вопрос о необходимости уточнения линии границы, считая, что пограничная комиссия необоснованно передала Туве часть территории, принадлежащей МНР, и при проведении границы в 1932 г. не были учтены исторические материалы.

Пограничный режим не соблюдался, монголы кочевали на территориях, отошедших к ТНР, и наоборот, соответственно случались пограничные инциденты, когда тувинцы и монголы претендовали на одни и те же участки земли. Так, из записей М. Сущевского мы узнаем, что в ноябре 1942 г. монгольские пограничники задержали тувинского арата в районе Эрзин и продержали неделю под арестом. На протест тувинского правительства ответа от правительства МНР не последовало (АВП РФ. Ф. 06, оп. 5, п. 31, д. 363, л. 3). Через несколько месяцев, 27 апреля 1943 г. А. Чимба ознакомил М. Сущевского с нотой X. Чойбалсана. Монгольское правительство протестовало против того, что араты ТНР пытаются провести сев яровых на спорных территориях хошунов Монгун-Тайга, Овюр, Эрзин (АВП РФ. Ф. 06, оп. 5, п. 31, д. 363, л. 20).

После вхождения в октябре 1944 г. Тувы в состав СССР советские пограничные войска взяли под охрану границу между СССР и МНР в пределах Тувинской Автономной области (ТАО) вдоль указанной линии 1932 г., в результате чего спорные участки, на которые претендовали монголы, оказались в советских пределах. Тогда же советское правительство сообщило монгольскому, что до уточнения линии границы монголам разрешается проживать и кочевать на спорных территориях на тех же условиях, что и ранее (РГАСПИ. Ф. 17, оп. 137, д. 144, л. 18). Советско-монгольская граница в пределах тувинско-монгольского участка была четко определена и демаркирована лишь соглашением 26 марта 1958 г. Позже делегации двух стран провели проверку и уточнение границы XVIII-XIX вв., и 19 октября 1976 г. был подписан новый договор о прохождении границы (Капица, 1996: 200-201).

${ }^{1}$ Ш. Лопсан-Самбу и Т. Сюрюн были арестованы весной 1943 г. как участники «группы» С. Чурмит-Дажы, не выявленные в ходе следствия 1938 г. Летом 1943 г. судебная коллегия МВД ТНР приговорила их к длительным срокам заключения: Ш. Лопсана-Самбу - к 25 годам исправительно-трудовых лагерей, Т. Сюрюна - к 20 годам. В 1961 г. оба были реабилитированы из-за отсутствия состава преступления (Иргит, 2019: 165-166).

${ }^{2}$ А. И. Лангфанг входил в руководство НКВД СССР, в 1942 г. выполнял спецзадания в Туве и МНР. 
С установлением новых границ между СССР и МНР и началом коллективизации, власти двух стран начали принимать меры по массовому переселению этнических тувинцев с территории Монголии в Туву. Так, часть соянов, кыргысов и чооду, проживавшая вокруг хребта Хан-Когей, была переселена в Туву и утратила родовые кочевья в Западной Монголии (Донгак, 2018: Электр. ресурс). Процесс этот начался еще в 1930-е гг., после заключения договора 1932 г. ${ }^{1}$ Были такие переселения, носившие принудительный характер, и в дальнейшем, в 1940-е гг. ${ }^{2}$ Так, в дневнике миссии СССР в ТНР есть следующая запись за 13 ноября 1943 г.: «Тока только что вернулся из Тесхема (хошун), он рассказал, что монголы начали перекочевку в Туву. Тока доброжелательно относится к перекочевке монголов» (АВП РФ. Ф. 06, оп. 5, п. 31, д. 363, л. 70).

Переселение части тувинских аратов в МНР, начавшееся в 1930-е гг., продолжалась и в последующие десятилетия. Так, из записей М. Сущевского мы узнаем, что осенью 1943 г. в МНР из Тоджи откочевало 11 хозяйств, и они не собирались возвращаться обратно. Тогда С. Тока и советник ЦК ТНРП Я. К. Калиничев, взволнованные этим сообщением, ездили в Тоджу искать «антипартийные группировки» (АВП РФ. Ф. 06, оп. 5, п. 31, д. 363, л. 58). Их тогда находили то в одном, то в другом хошуне: 1943-1944-е годы стали годами значительного усиления борьбы с «контрреволюцией»: всего за два года было ликвидировано более 20 крупных «контрреволюционных» групп (Иргит, 2019: 169).

После вхождения Тувы в состав СССР (1944 г.) стали создаваться колхозы, происходил переход кочевников на оседлый образ жизни. Из Тоджи и Кунгуртуга в Хубсугульский аймак МНР в 1940-1950-х годах перекочевало много семей, избегая оседлой жизни, реквизиции домашнего скота, призыва в Советскую Армию во время Второй мировой войны, репрессий, постепенной советизации и русификации тувинского общества, сетуя на дефицит продовольствия в Туве военного и послевоенного времени. Там они присоединялись к небольшому количеству тувинцев, уже проживавшему на этих землях (Монгуш, 2010: 224). Часть тувинских семей смогла перегнать через границу своих оленей. Сначала они считались людьми без гражданства. Только после установления границы в 1950-х гг. тувинцы были признаны гражданами Монголии (Биче-оол, Самдан, 2012: 33).

\section{Из повседневной жизни тувинского общества}

За год до знаменательных событий в жизни Тувы, 7 июля 1943 г. М. Г. Сущевский даже обсуждал с С. Токой и А. Чимбой организацию дипломатического агентства ТНР в Абакане (АВП РФ. Ф. 06, оп. 5, п. 31, д. 363, л. 36). Этот вопрос возник потому, что через Абакан проходило большое количество рабочих, грузов и т. п., обслуживание которых должны были нести местные областные организации (обком, облисполком, облвоенкомат и пр.). В частности, через Абаканский облвоенкомат шел прием тувинских добровольцев, отправляющихся служить в Красную армию для участия в военных действиях. Вообще же разнообразные контакты между ТНР и Хакасской автономной областью, включая обоюдные визиты партийного руководства на торжественные мероприятия, укреплялись, начиная с 1930-х гг. Учитывая нехватку жилья, фиксировались жалобы на большие неудобства при проезде представителей Тувы. В Абакане не было гостиницы, открытой столовой. Поэтому советский дипломат рекомендовал тувинскому правительству обсудить организацию со следующего года дипломатического агентства в Абакане, сооружения дома (с небольшим отелем), гаража и т. п. Тока пообещал на ближайшем заседании правительства обсудить этот вопрос, предварительно увязав его с бюджетом (АВП РФ. Ф. 06, оп. 5, п. 31, д. 363, л. 36).

Дневники М. Сущевского проливают свет, в частности, на историю создания известного тувинского музея. Так, 29 июля 1943 г. М. Сущевский беседовал с тувинским премьером А. Чимбой о приобретении дома в п. Суг-Бажы (ныне село Кочетово), в котором проходил с 13 по 16 августа 1921 г. Всетувинский Учредительный хурал, провозгласивший создание Тувинской Народной Республики и принявший ее первую Конституцию. Сущевский писал: «По полученным мною сведениям этот дом, владелица его, гр-ка Глаголева решила продать, а самой уехать в город. Так как этот дом представляет большую историческую ценность для Тувы, я рекомендовал Чимба купить его у Глаголевой (стоит он всего 300 акша) и организовать в нем отделение музея. Чимба согласился со мной и поблагодарил за это предложение» (АВП РФ. Ф. 06, оп. 5, п. 31, д. 363, л. 42). Сейчас это здание входит в состав Кочетовского историко-мемориального комплекса.

\footnotetext{
1 Чооду, К.-К. К. (2011) Черный орел Эзир-Кара // Центр Азии. № 10 (19 марта).

${ }^{2}$ Пользуюсь случаем выразить признательность В. С. Орус-оолу, который привлек мое внимание к этой проблеме.
} 
В то же время, судя по записям миссии, можно заключить, что взаимоотношения между советскими представителями и тувинской стороной не всегда протекали гладко. 2 ноября 1943 г. в советской миссии в Кызыле было проведено совещание со специалистами, состоявшими на службе у тувинского правительства. Обсуждался вопрос о ненормальностях в поведении специалистов и их взаимоотношениях с тувинскими работниками. Речь шла о грубости, заносчивости и нетактичности некоторых советских специалистов по отношению к тувинским коллегам. Было указано на необходимость прекращения подобных явлений (АВП РФ. Ф. 06, оп. 5, п. 31, д. 363, л. 66). Тувинскому руководству также не нравилось, что некоторые советские специалисты (среди них и А. Пальмбах, один из создателей тувинской письменности) в рабочее время, совместительствуя, вели педагогическую работу и получали дополнительную оплату. Часто этих специалистов не оказывалось на рабочем месте, в учреждении, и никто не знал, где они находятся, так как администрацию не ставили в известность (АВП РФ. Ф. 06, оп. 5, п. 31, д. 363, л. 58). У советской стороны находились свои поводы для недовольства: например, когда тувинские министры недостаточно прислушивались к приставленным к ним советским советникам. Так, 14 сентября 1943 г. М. Сущевский обсуждал вопрос «о ненормальном отношении министра просвещения Лапсанара к советнику Министерства Галилову и директору средней русской школы т. Григоренко»: «Министр Просвещения Лопсанар по целому ряду вопросов обходит советника, не согласовывает свои распоряжения с ним, часто спорит по пустякам, недостаточно внимателен, хотя сам плохо разбирается в педагогических вопросах» (АВП РФ. Ф. 06, оп. 5, п. 31, д. 363, л. 52).

Некоторое отображение в записях М. Сущевского получило и отношение старообрядцев, в частности, одного из их лидеров - знаменитого о. Палладия, к общественно-политической ситуации, сложившейся в Туве в первой половине 1940-х гг. М. Сущевский рассказывал о своей беседе с председателем Ильинского поселкового хурала о «выполнении староверами своих обязательств перед государством», которая имела место 21 октября 1943 г. Советский дипломат отмечал, что староверы по-прежнему отрицательно относятся к службе в Красной армии и оказанию ей материальной помощи. Он, в частности, писал: «Руководитель староверов отец Палладий скрывающийся в тайге дал указание староверам давать подарки Красной Армии только при условии административного давления, только в крайнем случае и в небольших количествах. К русскому духовенству, участвующему активно в помощи Красной Армии, громящей немецких захватчиков староверы относятся враждебно никак не разделяют их действий» (АВП РФ. Ф. 06, оп. 5, п. 31, д. 363, л. 61). По словам российских исследователей, в собрании старопечатных и рукописных книг отца Палладия, несколько десятилетий руководившего старообрядцами верхнего Енисея, имелся сборник урало-сибирских старообрядческих сочинений, содержавший уложения и постановления соборов старообрядцев часовенного согласия на протяжении XVIII-XX вв. Ими и руководствовался наставник, принимая важные для жизни общины решения (Татаринцева, Стороженко, 2015: 75-76). Постепенно жизнь вносила свои поправки, количество запретов несколько уменьшилось уже на памяти одного-двух поколений приверженцев старой веры, и сам о. Палладий в конце жизни пообещал, что не будет больше возражать против службы староверов в армии (там же: 76, 121).

\section{Заключение}

Дневниковые записи поверенного в делах СССР в ТНР М. Г. Сущевского позволяют пролить свет на политическую ситуацию в ТНР накануне вхождения в состав СССР, проанализировать ранний этап этого процесса и локализировать, как нам кажется, хронологическую дату, с которой советское руководство начало прорабатывать этот вопрос - 18 марта 1943 г.

Обращает на себя внимание, что решение, к которому склонялась Москва, еще более года оставалось в тайне. Внешне советская сторона очень внимательно подходила к «сохранению дистанции» по отношению к ТНР, оставляя себе свободу политического маневра. Об этом свидетельствует дискуссия вокруг тувинской военной формы и знаков отличия. Неизменно подчеркивалось, что Тува - независимое, суверенное государство, которое должно иметь свою форму с государственной символикой, надписями на тувинском языке. В этом же ракурсе можно рассматривать и планы открытия дипломатического агентства ТНР в Абакане, и подчеркнутое внимание к истокам тувинской государственности (история со зданием, в котором в 1921 г. проходил Всетувинский Учредительный хурал).

При изучении судьбоносного решения 1944 г., принятого тувинским руководством, интересны и обстоятельства получения С. Токой высокого воинского звания генерал-лейтенанта, описанные М. Сущевским. Так мы узнаем, что Президиум Малого хурала не всегда собирался, чтобы обсудить и 
принять то или иное решение - в некоторых случаях могло просто обнародоваться нужное решение от его имени, а также то, что тувинский политикум, пребывающий под постоянной угрозой репрессий, не решался возражать С. Токе.

Записи М. Сущевского позволяют увидеть некоторое отстранение и изоляцию советских дипломатов в 1940-е гг. от процесса фабрикации политических дел, который продолжался в ТНР. В то же время очевидны участие С. К. Токи в этих процессах и его осведомленность. Поэтому награждение его почетным значком НКВД СССР, которым награждались представители МВД ТНР, выглядит даже символичным.

Отношения с МНР оставались важным и болезненным вопросом для тувинского руководства, который, помимо вопроса о границе, усугублялся непрекращающейся с 1930-х гг. эмиграцией тувинцев в Западную Монголию.

\section{СПИСОК ЛИТЕРАТУРЫ}

Биче-оол, С. М., Самдан, А. А. (2012) Оленеводы Восточных Саян Республики Тыва и Монголии // Вестник Тувинского государственного университета. Социальные и гуманитарные науки. Кызыл. Вып. 1. С. 31-37.

Донгак А. С. (2018) Топонимические предания и легенды Юго-Восточной Тувы [Электронный peсурс]//Новые исследования Тувы. № 3. URL: https://nit.tuva.asia/nit/article/view/793 (дата обращения: 20.03.2019). DOI: $10.25178 /$ nit.2018.3.9

Иргит, О. Ю. (2019) Политические репрессии в Тувинской Народной Республике в 1921-1944 гг.: дисс. .... к-та ист. наук. Кызыл. 213 с.

Капица, М. С. (1996) На разных параллелях. Записки дипломата. М. : Книга и бизнес. 480 с.

Моллеров, Н. М. (2005) Советско-тувинские отношения: 1917-1944 гг.: дисс. ... д-ра ист. наук. М. 465 с.

Монгуш, М. В. (2010) Один народ: три судьбы: Тувинцы России, Монголии и Китая в сравнительном контексте. Осака : Национальный Музей Этнологии. 360 с.

Ондар, Е. М. (2016) К вопросу об особенностях политического развития Тувинской Народной Республики в 1920-1930-е годы // Вестник Томского государственного педагогического университета. № 12 (177). С. 158-164.

Салчак Тока (2015) / [У. А. Донгак, и др.; под общ. ред. С. К. Шойгу и др.]; Русское географическое о-во, ТИГПИ. М. : Слово. 544 с.

Татаринцева, М. П., Стороженко, А. А. (2015) Старообрядцы Тувы: ретроспектива и современность. Сборник научных статей. Lambert Academic Publishing. 138 с.

Харунова, М. М. (2011) Социально-политическое развитие Тувы в середине XX века. Новосибирск : Наука. 135 с.

Дата поступления: 01.08.2019 г.

\section{REFERENSES}

Biche-ool, S. M. and Samdan, A. A. (2012) Olenevody Vostochnykh Saian Respubliki Tyva i Mongolii [East Sayan reindeer herders from the Republic of Tyva and Mongolia]. Vestnik Tuvinskogo gosudarstvennogo universiteta. Sotsial'nye i gumanitarnye nauki. Issue 1. Pp. 31-37. (In Russ.).

Dongak, A. S. (2018) Toponimicheskie predaniia i legendy yugo-vostochnoi Tuvy [Toponymic Legends of South-Eastern Tuva]. The New Research of Tuva, 2018, no. 3 [on-line] Available at: https://nit.tuva.asia/nit/ article/view/793 (access date: 20.03.2019). DOI: 10.25178/nit.2018.3.9 (In Russ.).

Irgit, O. Iu. (2019) Politicheskie repressii v Tuvinskoi Narodnoi Respublike v 1921-1944 gg. [Political repressions in the Tuvan People's Republic in 1921-1944]: Diss.... Candidate of Politic Sciences. Kyzyl. 213 p. (In Russ.).

Kapitsa, M. S. (1996) Na raznykh paralleliakh. Zapiski diplomata [On various parallels. Notes by a diplomat]. Moscow, Kniga i biznes. 480 p. (In Russ.).

Mollerov, N. M. (2005) Sovetsko-tuvinskie otnosheniia: 1917-1944 gg. [Soviet-Tuvan relations: 1917-1944]. Diss.... Doctor of History. Moscow. 465 p. (In Russ.). 
Mongush, M. V. (2010) Odin narod: tri sud'by. Tuvintsy Rossii, Mongolii i Kitaia v sravnitel'nom kontekste [One people, three destinies. Tuvans of Russia, Mongolia and China in a comparative context]. Osaka, Natsional'nyi muzei etnologii. 358 p. (In Russ.).

Ondar, E. M. (2016) K voprosu ob osobennostiakh politicheskogo razvitiia Tuvinskoi Narodnoi Respubliki v 1920-1930-e gody [On the peculiarities of the political development of the Tuvan People's Republic in the 1920-1930s]. Vestnik Tomskogo gosudarstvennogo pedagogicheskogo universiteta, no. 12 (177), pp. 158-164. (In Russ.).

Salchak Toka (2015) Ed. by S. K. Shoigu at al. Moscow, Slovo. 544 p. (In Russ.).

Tatarintseva, M. P. and Storozhenko, A. A. (2015) Staroobriadtsy Tuvy: retrospektiva i sovremennost' [Old Believers of Tuva: retrospective and modernity]. Saarbrucken, Lambert Academic Publishing. 137 p. (In Russ.).

Kharunova, M. M. (2011) Sotsial'no-politicheskoe razvitie Tuvy $v$ seredine XX veka [Sociopolitical development of Tuva in the mid-twentieth century]. Novosibirsk, Nauka. 135 p. (In Russ.).

Submission date: 01.08.2019. 